\title{
Suppression of kidney fibrosis by cGMP- dependent protein kinase I
}

\author{
Elisabeth Schinner ${ }^{1 *}$, Armin Kurtz², Franz Hofmann ${ }^{3}$, Jens Schlossmann ${ }^{1}$ \\ From 5th International Conference on cGMP: Generators, Effectors and Therapeutic Implications \\ Halle, Germany. 24-26 June 2011
}

\section{Background}

cGMP is synthesized via nitric oxide- or natriuretic peptide-stimulated guanylyl cyclases and exhibits pleiotropic regulatory functions also in the kidney. Hence, the integration of cGMP signaling via cGMP-dependent protein kinases (cGK) might play a critical role for renal physiology. Both isozymes were detected in arterioles, mesangium and within the cortical interstitium. In contrast to cGKI $\alpha$, the $\beta$ isoform was not detected in the juxtaglomerular apparatus and medullary fibroblasts.

\section{Results}

Here, we examined the function of cGKI in the renal interstitium emphasizing a functional differentiation of both isoforms. The interstitium exists mainly of fibroblasts playing a prominent role in the interstitial fibrosis. Accordingly, cGKI could also be involved in this pathophysiological process. Therefore, we studied whether cGKI influences renal fibrosis by application of cGMP increasing $\mathrm{YC}-1$ or ISDN and by using mutant mice. The kidney-fibrosis was induced by unilateral ureter obstruction (UUO).

\section{Conclusion}

Administration of ISDN showed significantly antifibrotic effects in wt- but not in $\alpha \mathrm{SM}$-rescue mice. Also tg-tg mice which express more cGKI $\alpha$ developed significantly less fibrosis than wt mice. Moreover, mRNA- and protein expression of cGKI $\beta$ was fewer influenced by fibrosis than cGKI $\alpha$. Accordingly, our results indicate that cGMP acts primarily via cGKI $\alpha$ as an important suppressor of kidney fibrosis.

\section{Author details}

${ }^{1}$ Pharmakologie und Toxikologie, Universität Regensburg, Germany.

${ }^{2}$ Physiologie, Universität Regensburg, Germany. ${ }^{3}$ Carvas-Zentrum, TU München, Germany.

Published: 1 August 2011

doi:10.1186/1471-2210-11-S1-P62

Cite this article as: Schinner et al:: Suppression of kidney fibrosis by cGMP-dependent protein kinase I. BMC Pharmacology 2011 11(Suppl 1): P62.
Submit your next manuscript to BioMed Central and take full advantage of:

- Convenient online submission

- Thorough peer review

- No space constraints or color figure charges

- Immediate publication on acceptance

- Inclusion in PubMed, CAS, Scopus and Google Scholar

- Research which is freely available for redistribution
C Biomed Central 